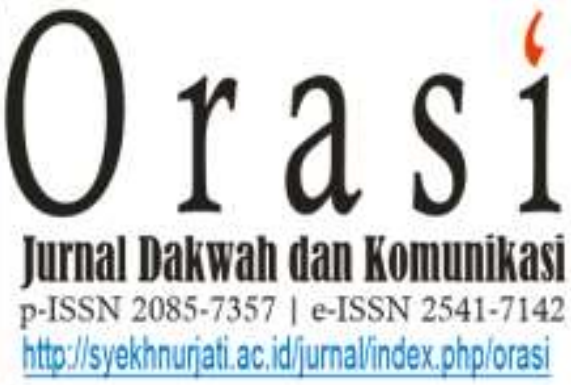

Volume 12 No. 1 Juli 2021

\title{
MEDIA SOSIAL SEBAGAI ALAT KOMUNIKASI DAKWAH PADA MASA PANDEMI
}

\section{SOCIAL MEDIA AS A DA'WAH COMMUNICATION TOOL IN THE PANDEMIC TIME}

\author{
Asriyanti Rosmalina ${ }^{1, a)}$, Tia Khaerunnisa ${ }^{2, b)}$ \\ ${ }^{1,2}$ Jurusan Komunikasi Penyiaran Islam, IAIN Syekh Nurjati Cirebon \\ Jl. Perjuangan By Pass Sunyaragi Cirebon \\ e-mail: a) asriyantirosmalina@gmail.com, \\ b)tiakhaerunnisa@gmail.com
}

\begin{abstract}
ABSTRAK
Teknologi telah berkembang pesat, hal tersebut dikarenakan teknologi sudah menjadi kebutuhan primer oleh masyarakat. Perkembangan teknologi tidak dapat dihilangkan dari aktifitas kehidupan sehari-hari, semua aktifitas keseharian dapat dengan mudah dan cepat karena bantuan teknologi. Salah satunya dalam aspek informasi dan komunikasi. Komunikasi merupakan suatu proses penyampaian pesan dari seorang komunikator kepada orang lain (komunikan) untuk memberikan informasi atau mengubah sikap, pendapat maupun perilaku dengan melalui lisan ataupun melalui media. Hadirnya media sosial memberikan peluang yang terbuka dalam proses penyebaran dakwah islam. Media sosial dilihat sebagai media massa yang mampu menyampaikan pesan dakwah dalam cakupan yang begitu luas dan ruang yang tidak terbatas. Pada masa pandemi virus covid 19 , merupakan keadaan yang tidak berada dalam kondisi normal yang dapat memberikan dampak dalam berbagai aspek kehidupan, di mulai dari aspek sosial, aspek pendidikan, aspek ekonomi dan bahkan berdampak pula pada aspek keagamaan yang berkaitan dengan kegiatan keagamaan yaitu kajian-kajian dakwah. Sehingga dengan menggunakan media sosial dapat memudahkan pesan dakwah islam menyebar luas ke seluruh dunia tanpa adanya rasa khawatir akan penyebaran virus covid 19.
\end{abstract}

Kata Kunci :Media Sosial, Alat Komunikasi Dakwah, Pandemi. 
Technology has developed rapidly because it has become a primary need for society. Technological developments cannot be removed from daily life activities. All daily activities can be done easily and quickly because of the help of technology. One of the activities is in the aspect of information and communication. Communication is a process of delivering messages from a communicator to other people (communicants) to provide information or change attitudes, opinions or behavior by verbal or through a medium. The presence of social media provides open opportunities in the process of spreading Islamic da'wah. Social media is seen as a mass media that is able to convey da'wah messages in such a wide scope and unlimited space. During the COVID-19 pandemic, this so-not-normal condition have an impact on various aspects of life, starting from the social aspect, educational aspect, economic aspect, to religious aspects, such as da'wah studies. Therefore, by using social media, it becomes easier for the message of Islamic da'wah to spread widely throughout the world without any worries about the spread of the COVID-19 virus.

Keywords: Social Media, Da'wah Communication Tool, Pandemic.

\section{Pendahuluan}

Pada masa kini, teknologi telah berkembang sangat pesat, hal tersebut dikarenakan teknologi dikembangkan untuk menjadi alat yang dapat memberikan kemudahan kepada penggunanya agar dapat membantu penggunanya dalam melakukan aktifitas secara efisien.Sehingga dengan hadirnya teknologi ini menjadikannya sebagai kebutuhan primer bagi masyarakat untuk dapat membantu segala aktifitas kegiatan masyarakat. Perkembangan teknologi tidak dapat dihilangkan dari kehidupan sehari-hari, semua aktifitas keseharian dapat dengan mudah dan cepat karena bantuan teknologi. Salah satunya dalam bidang informasi dan komunikasi.

$$
\text { Dalam penggunaan teknologi }
$$

memberikan sarana kepada penggunanya untuk dapat berkomunikasi dan menyebarkan informasi dengan mudah tanpa ada batasan ruang dan waktu.Salah satunya adalah untuk menyebarkan informasi dakwah melalui teknologi. Allah memberikan perintah kepada umatnya untuk melakukan tugas suci yaitu berdakwah. Dengan bantuan teknologi memudahkan para da'i untuk berdakwah tanpa perlu mengkhawatirkan waktu dan ruang, selain itu juga dapat memudahkan masyarakat untuk mengakses dakwah secara mudah.

Masyarakat seringkali memahami bahwa dakwah merupakan tugas yang diberikan kepada seseorang yang memiliki gelar ustadz, kyai, ajengan dan gelar ulama (Rustandi 2019, 95). Setiap umat manusia memiliki latar belakang profesinya masing-masing dan di wajibkan baginya untuk menyampaikan dakwah islam sesuai dengan perannya. Seorang ulama melakukan perjalanan dakwah melalui jalan perjuangannya, seorang penguasa berdakwah melalui kekuasaannya, seorang dokter, dosen dan juga guru berdakwah melalui ilmunya, seorang pedagang, petani dan nelayan berdakwah melalui profesinya. 
Pada masa ini, menyebarkan pengetahuan tentang islam tidak selalu hanya dilakukan oleh seorang ulama. Berdakwah dapat dilakukan dimana saja, kapan saja dan dengan cara yang bermacam-macam orang bisa mendapatkan ilmu agama islam. Masyarakat sekarang ini tidak hanya mengandalkan ulama sebagai satu-satunya sumber untuk belajar agama islam. Masyarakat dapat menggunakan handphone bahkan media sosial sebagai alat untuk mempelajari agama dengan berbagai pengetahuan yang berkaitan dengan problematika ringan seputar ibadah hingga problematika rumit sekalipun, semuanya dapat dengan mudah diketahui dan didapatkan (Fauzi 2020, 29).

Hadirnya media sosial memberikan peluang yang terbuka dalam proses penyebaran dakwah islam. Media sosial dilihat sebagai media massa yang mampu menyampaikan pesan dakwah dalam cakupan yang begitu luas dan ruang yang tidak terbatas. Penggunaan media sosial sebagai alat dakwah dilengkapi dengan kreatifitas dan inovasi para da'i dalam memanfaatkan penggunaan teknologi untuk keberlangsungan dakwah islam (Rustandi 2019, 95).

Namun, di dalam keberlangsungan kehidupan yang semakin pelik dengan hadirnya virus 2019-nCoV atau Covid-19 yang berasal dari kota Wuhan, China tersebut membuat masyarakat menjadi terpuruk dalam keadaan yang disebabkan oleh virus tersebut. Sebagain masyarakat terkena psikosomatis, yang disebabkan oleh rasa cemas yang berlebih karena hadirnya covid-19 tersebut (Rahma and Mada Wijaya Kusumah 2020, 43).

Dengan begitu, peran seorang pendakwah sebagai pembimbing serta pencerah tidak boleh dibatasi oleh ruang dan waktu.Ilmu yang dimiliki oleh seorang da'i harus membuat inovasi yang baru agar dakwah tidak terhenti hanya karena masalah-masalah yang kecil. Melakukan pemanfaatan media sosial merupakan salah satu cara yang mampu memberikan layanan yang memungkinkan dalam kebijakan lockdown pada saat ini, menggantikan dakwah yang secara langsung berinteraksi dengan banyak orang.

Bentuk dari hadirnya media sosial yaitu banyaknya dari kalangan masyarakat menggunakan media sosial sebagai sarana untuk menyebarkan dakwah dengan memanfaatkan layanan forum yang di sediakan oleh whatsapp, facebook, youtube, twitter dan instagram untuk bertukar informasi.

Di samping itu, media sosial tidak hanya digunakan oleh para remaja saja, namun anakanak bahkan orang dewasa ikut menikmati penggunaan media sosial untuk berkomunikasi dan bertukar informasi dilihat bahwa pada masa kini anak-anak aktif dalam penggunaan media sosial secara bebas. Dengan bermodal handphone dan kuota internet mereka dapat mengakses media sosial dengan mudah dan praktis. Bahkan untuk kegiatan menyebarkan dakwah, masyarakat dapat dengan mudah 
mendapatkan informasi dakwah dengan menggunakan media sosial.

Namun, yang menjadi permasalahannya adalah mengenai seperti apa masyarakat indonesia menjalankan proses dakwahnya bila disandingkan dengan pada masa pandemi virus corona sekarang ini. Fenomena tersebut tentu perlu kita ketahui mengenai bagaimana penggunaan media sosial sebagai alat dakwah pada masa pandemi virus corona tersebut.

\section{Metode Penelitian}

\subsection{Jenis Penelitian}

Penelitian kualitatif merupakan
penelitian yang memiliki tujuan untuk
memahami fenomena tentang apa yang dialami
subjek penelitian misalnya perilaku, persepsi,
motivasi, dan tindakan secara holistik dengan
cara mendeskripsikan dalam bentuk kata-kata
dan bahasa pada suatu konteks khusus yang
alamiah dengan memanfaatkan berbagai metode
ilmiah (Lexy Joleong 2009,6).
ilmiah (Lexy J Moleong 2009, 6).

Penelitian ini mendeskripsikan tentang penggunaan media sosial sebagai alat komunikasi dakwah pada masa pandemi covid19. Artinya peneliti hanya mendeskripsikan penggunaan media sosial sebagai alat komunikasi dakwah pada masa covid-19 apa adanya tanpa memberikan perlakuan tertentu terhadap subjek maupun objek penelitian.

Teknik pengumpulan data yang peneliti pergunakan dalam penelitian ini adalah sebagai berikut:

1) Observasi
2) Wawancara
3) Dokumentasi

\subsection{Pendekatan Penelitian}

Pada penelitian ini peneliti menggunakan pendekatan penelitian grounded theory atau teori dasar didefinisikan oleh para ahli sebagai pendekatan metode penelitian kualitatif yang menggunakan seperangkat prosedur sistematik untuk mengembangkan teori dari dasar yang diperoleh secara induktif tentang suatu fenomena (Lexy J Moleong 2009, 25).

\section{Hasil dan Pembahasan}

\subsection{Komunikasi Dakwah}

Kata dakwah secara etimologis merupakan bentuk masdar yang berasal dari kata yad'a, yad'u, da'watan, yang artinya memanggil, mengundang, menyeru, mengajak dan mendorong. Sedangkan secara terminologis, dakwah merupakan bentuk mengajak dan menyeru umat islam untuk berpedoman hidupyang diridhai Allah STW dalam bentul amar ma'ruf nahi munkar. Menurut Helmy (Helmy 1976, 61) mengatakan bahwa dakwah islam merupakan dakwah yang mengajak dan menggerakkan manusia supaya mengikuti ajaran-ajaran Allah yaitu islam, termasuk melakukan amar ma'ruf nahi munkar sehingga bisa membawa kebahagiaan dinia dan akhirat.

Dakwah merupakan tugas yang begitu sangat mulia, Rasulullah diutus oleh Allah SWT untuk mendakwahi umat manusia. Namun untuk saat ini, sudah menjadi kewajiban bagi setiap 
umat muslim untuk berdakwah, namun menjadi pendakwah memanglah bukan hal yang mudah, dan tidak bisa dilakukan oleh sembarang orang. Seorang pendakwah harus memiliki persiapan yang memupuni dalam segi keilmuan dan juga dalam segi budi pekerti. Karena jika seorang pendakwah atau seorang da'i kurang memupuni dalam segi keilmuan dan juga dalam segi perilaku maka akan sulit untuk dilakukan (AnNabiry 2008).

Sedangkan komunikasi merupakan suatu proses penyampaian pesan dari seseorang kepada orang lain untuk memberikan informasi atau mengubah sikap, pendapat maupun perilaku dengan melalui lisan ataupun melalui media (Soyomukti 2012, 11). Istilah komunikasi dalam bahasa inggris yaitu communication yang berasal dari kata latin yaitu communicatio, communis yang artinya "sama makna". Sama di sini maksudnya adalah sama makna. Apabila dua orang terjalin dalam komunikasi, misalnya dalam bentuk percakapan, maka komunikasi akan berlangsung selama adanya kesamaan makna mengenai apa yang menjadi topik percakapan.

Menurut Miller dalam buku (Ngalimun 2017, 8) mengatakan bahwa komunikasi merupakan situasi-situasi yang memungkinkan suatu sumber penyampaian pesan kepada komunikan dengan niat yang disadari untuk mempengaruhi perilaku komunikan. Dalam definisi ini, miller memperluas pengertian komunikasi dengan tujuan untuk mempengaruhi perilakunya.Dengan begitu meller mengatakan bahwa komunikasi tidak hanya sekedar menyampaikan pesan, lambang atau tanda tapi juga untuk mempengaruhi seseorang atau beberapa orang melakukan sesuatu atau melakukan tindakan tertentu.

Berdasarkan dua pengertian komunikasi dan dakwah diatas, Ahmad Mubarak dalam buku Psikologi Dakwah mengatakan bahwa kegiatan dakwah merupakan proses komunikasi, yang dimana da'i menyampaikan isi materi kepada jama'ah adalah salah satu bentuk dari komunikasi, dimana da'i sebagai seorang penyampai atau komunikator dan jama'ah sebagai komunikan. Secara teknis, dakwah adalah komunikasi, dai merupakan komunikator, dan mad'u merupakan komunikan. Semua aspek dalam ilmu komunikasi berlaku juga dalam dakwah, begitu juga pada hambatan komunikasi juga berkapu pada hambatan dakwah.

Dalam berdakwah melibatkan lima unsur, yaitu unsur da'i atau subyek, maaddah atau materi, thoriqoh atau metode, wasilah atau media, dan juga mad'u atau objek. Dakwah memiliki tujuan yang beintegrasi dengan tujuan islam yaitu mencapai untuk kebahagian hidup di dunia dan juga akhirat (Saputra 2011).

1. Da'i atau Subyek

Da'i merupakan orang yang melakukan atau menyampaikan sebuah informasi yang berisikan tentang dakwah secara lisan maupun lisan kepada individu maupun kepada kelompok objek atau mad'u (Renel 2012, 41). Namun pada hakikatnya seorang da'i tidak hanya diperuntukkan bagi seorang ustadz maupun 
ulama, namun setiap umat Nabi Muhammad tentu dianjurkan mampu berdakwah sesuai dengan kemampuan individu tersebut.

Dakwah tidak akan sukses apabila pendakwah atau seorang da'i tidak merelakan dirinya secara keseluruhan dalam berjuang di jalan Allah. Dakwah yang sukses adalah dakwah yang dengan efektif dalam membimbing umat manusia untuk melakukan yang ma'ruf fan mencegah dari yang mungkar.

\section{Maddah atau Materi Dakwah}

Sebagai seorang muslim yang beriman, kita di fardukan untuk menyampaikan dakwah walaupun hanya satu ayat. Pada masa teknologi yang canggih ini, dapat dengan mudah memilih strategi, metode dan media yang bagaimana untuk melaksanakan dakwah.Materi dakwah yang disampaikan kepada obyek atau mad'u disesuaikan dengan tingkat kemampuan dan kebutuhan mad'u secara umum dengan dikelompokkan sebagai berikut:

a) Akidah, mad'u yang memiliki kebutuhan mengenai akidah yang meliputi enam Rukun Iman, diantaranya yaitu Iman kepada Allah, Iman Kepada Malaikat Allah, Iman kepada KitabKitab Allah, Iman kepada RasulRasulnya, Iman kepada hari Kiamat dan Iman Kepada Qodo dan Qodar.

b) Syariah, mad'u yang memiliki kebutuhan yang meliputi peribadatan yaitu Cara Bersuci, Sholat, Zakat, Puasa dan Haji. c) Muamalah, yaitu meliputi hukum Perdata, hukum Niaga, hukum Nikah, hukum Waris dan lain sebagainya termasuk Hukum Publik di antara lainnya hukum Negara, jihad dan lainnya.

d) Akhlak yaitu meliputi akhlak terhadap Allah, akhlak terhadap sesama manusia dan akhlak terhadap lingkungan (Renel 2012, 43).

Materi dakwah yang disampaikan oleh da'i biasanya disesuaikan dengan tema di setiap akun media sosial tersebut, media sosial tersebut dapat berisikan materi mengenai akidah, syariah, muamalah maupun akhlak sesuai dengan materi yang disampaikan oleh da'i.

Dengan adanya media sosial penyebaran informasi dakwah mudah di sebarkan dan di dapatkan sesuai dengan problematika hidup masyarakat yang sedang di hadapi. Namun dalam memberikan materi dakwah para da'i perlu memperhatikan daya nalar subyek atau mad'u sehingga mampu menangkap informasi dakwah dengan baik.

Aspek yang perlu diperhatikan oleh da'i antara lain adalah aspek lingkungan, budaya, agama dan pendidikan mad'u. Ada beberapa faktor yang dapat mendorong keberhasilan dalam dakwah, di antaranya yaitu:
a) Keilmuan yang memadai
b) Keimanan yang teguh
c) Kecintaan yang kuat
d) Kesadaran yang totalitas
e) Kerja yang berkelanjutan 
Aspek tersebut menekankan pada pentingnya para da'i untuk membuat materi dakwah yang sesuai dengan mad'u mengenai tingkat kecerdasan mad'u. Dengan begitu para da'i harus mengemas materi dakwah ini dengan menggunakan bahasa yang ringan sehingga mudah dimengerti oleh mad'u dari semua kalangan.

3. Thoriqqoh atau Metode Dakwah

Dalam melakukan penyampaian dakwah tentu memegang pengaruh penting dalam menentukan thoriqqo atau metode dakwah, maka metode yang digunakan dalam penyampaian dakwah harus disesuaikan dengan mad'u. Apabila seorang da'i menggunakan metode yang tidak benar, maka pesan yang disampaikan oleh da'i akan ditolak oleh mad'u atau oleh penerima pesan. Ada tiga metode dakwah yang dapat dilakukan oleh da'i yaitu sebagai berikut:

\section{a) Al-Hikmah}

Toha Yahya Umar dalam Renel (2012, 47-48) menyatakan bahwa hikmah artinya meletakkan sesuatu pada tempatnya dengan cara berfikir, menyusun dan mengatur dengan cara yang sesuai dengan situasi zaman dan tentu tidak menentang dengan larangan Allah. Al-hikmah juga diartikan sebagai keadillan (al-adalah), kebenaran (al-Haq), dan ketabahan (al-hilan) serta al-hikmah juga dapat diartikan sebagai menempatkan sesuatu pada tempatnya.Hikmah merupakan suatu perkataan yang tegas disertai dengan dalil-dalil yang memperkuat dan menghilangkan rasa keraguan. b) Al-Mau'idzat al-Hasanah

Mau'idzat al-hasanah merupakan katakata yang masuk ke dalam hati dengan penuh rasa kasih sayang dan penuh kelembutan dalam memberikan nasihat seringkali dapat meluluhkan hati yang keras dan menjinakkan kalbu yang liar, dan lebih mudah menyampaikan kebaikan dari pada larangan maupun ancaman (Renel 2012, 51).

\section{c) Al-Mujadalah bi al-Ladzi Hiya Ahsan}

Al-mujadalah bil hiya ahsan merupakan cara berdakwah dengan bertukar pikiran atau berdiskusi yang memberikan kesempatan untuk bertanya jika ada hal-hal yang tidak difahami atau tidak setuju dan membentah dengan cara yang baik dan benar serta tidak memberikan tekanan-tekanan pada sasaran dakwah dan disertai dengan pendapat dan bukti yang kuat untuk menambah wawasan dalam segala aspek.

4. Wasilah atau Media Dakwah

Adapun hal-hal yang penting diperhatikan dalam metode dakwah antara lain yaitu bentuk penyampaian lisan (khutbah, pidato, ceramah, diskusi dan lain sebagainya), bentuk penyampaian tulisan (buku-buku, majalah, surat kuran, spanduk-spanduk, kuliahkuliah-kuliah tertulis pamphlet), bentuk penyampaian lukisan (gambar-gambar, hasil senilukis, foto, komik-komik bergambar), bentuk penyampaian audio visual, bentuk penyampaian lewat akhlak (silaturrahim, menjenguk orang yang sakit, membangun sekolah).

5. Mad'u atau obyek Dakwah 
Mad'u merupakan orang yang menjadi sasaran dakwah atau penerima dakwah baik secara individu maupun berkelompok, baik beragama islam maupun non-islam.

Mad'u atau subyek dakwah terdiri dari beberapa golongan, dengan begitu digolongkan dengan beberapa golongan sesuai dengan profesi, ekonomi dan lainnya. Penggolongan subyek dakwah dibagi beberapa golongan sebagai berikut:

a) Dari segi sosiologis (masyarakat terasing, pedesaan, perkotaan, kota kecil).

b) Dari struktur kelembagaan (golongan priayi, abangan, dan golongan orang tua).

c) Dari segi tingkatan usia (golongan anakanak, remaja dan orang tua).

Media-media baru seperti surat kabar, majalah, sosial media, jurnal, film, televisi, radio, lukisan, iklan, lagu dan yang lainnya dapat dengan mudah menyampaikan aktivitas dan pesan dakwah (Renel 2012, 55-56).

Dakwah yang disampaikan melalui media sosial dapat menggunakan metode dakwah yang berbeda-beda sesuai dengan layanan yang tersedia pada media sosial tersebut.Media sosial youtube, facebook, instagram biasanya menggunakan metode dakwah al-hikmah atau metode dakwah $A l$ Mau'idzat al-Hasanah.Sedangkan media sosial whatsapp menggunakan metode al-mujadalah atau media diskusi (dua arah).
Media sosial merupakan media internet yang memberikan kemudahan pada penggunanya untuk berinteraksi atau menginterpretasikan dirinya dengan orang lain dan membentuk sebuah ikatan dengan orang lain secara online atau secara virtual (Nasrullah 2015, 12). Media sosial memudahkan semua orang untuk berkomunikasi, berpartisipasi, saling berbagi dan membentuk sebuah komunitas (Hidayatun 2015). Media sosial sebagai alat komunikasi baru dapat memberikan dampak pada pergeseran pola dan cara interaksi dan komunikasi individu. Media sosial juga memberikan dampak positif dalam membiaskan geografis ruang dan waktu.Media sosial mampu menghubungkan individu dengan individu lainnya, individu dengan kelompok sosialnya, dan individu dengan kebutuhannya.Pada media sosial ini memudahkan untuk pertukaran pesan, gagasan, nilai dan tanda dalam suatu jaringan informasi, efektif dan dapat berlangsung secara kontinu.

Media sosial sebagai media baru bagi masyarakat mempunyai sifat yang terbuka. Maksudnya sebagai sebuah alat,media sosial dapat dengan mudah diakses oleh siapapun dan dapat digunakan untuk kepentingan apapun. Dengan begitu media sosial memberikan dampak positif yaitu keuntungan bagi para penggunanya. Mulai dari aspek dalam, edukasi, politik, informasi, rekreasi sampai aspek agama dan budaya.

Karakteristik media sosial memiliki karakter khusus (Nasrullah 2015, 24), yaitu: 


\section{Jaringan (Network)}

Jaringan merupakan infrastruktur yang menghubungkan antara komputer dengan perangkat keras lainnya.Hubungan ini diperlukan karena komunikasi bisa terjadi jika komputer terhubung yang didalamnya termasuk pada perpindahan data.

2. Informasi

Informasi merupakan hal penting di dalam media sosial karena pengguna media sosial melakukan interaksi sesuai dengan informasi yang didapat.

3. Arsip

Bagi pengguna media sosial, arsip menjadi alat untuk menyimpan informasi dan dapat dengan mudah diakses dengan menggunakan perangkat apa saja dan kapan saja.

4. Interaksi

Media sosial membentuk hubungan antara pengguna lainnya yang tidak hanya sekedar untuk memperluas hubungan pertemanan ataupun pengikut saja, tetapi juga dibangun dengan interaksi antar pengguna media sosial tersebut.

\section{Simulasi sosial}

Media sosial memiliki sifat sebagai medium berlangsungnya masyarakat di dunia online.Media sosial memiliki keunikan dan pola yang dalam beberapa kasus berbeda dan tidak di temui dalam tatanan masyarakat yang nyata.

6. Konten oleh pengguna
Dalam media sosial, penentuan konten sepenuhnya milik pengguna. Dalam penentuan konten, memberikan kesempatan kepada pengguna untuk memperluas partisipasinya dalam penggunaan media sosial. Berikut merupakan macam-macam media sosial di antaranya yaitu:

a) Facebook

Media sosial yang di dirikan oleh Mark Zurkerberg ini sangat populer di dunia maya, bahkan seluruh dunia juga menggunakan media sosial ini.Media sosial ini memiliki banyak kegunaan salah satunya sebagai tempat untuk diskusi dan belajar.Facebook dapat dimanfaatkan sebagai alat dakwah seperti gambar di bawah tersebut.

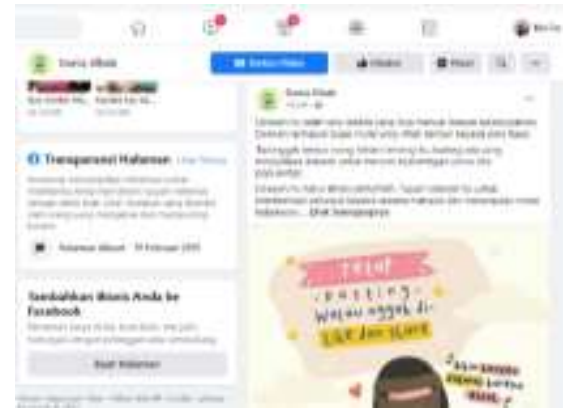

Gambar 1. Contoh media sosial facebook grup Dunia Jilbab sebagai alat dakwah

Penyampaian dakwah menggunakan media sosial facebook dapat dilakukan menggunakan forum grup facebook untuk membentuk grup dakwah, salah satunya adalah grup Dunia Jilbab, grup dunia jilbab berisikan berbagai materi mulai dari materi mengenai akidah, syari'ah, mu'amalah bahkan mengenai materi akhlak.

Media sosial facebook dengan forum grup biasanya menggunakan media dakwah 
dalam bentuk tulisan-tulisan, gambar-gambar komik, kuliah-kuliah bahkan dalam bentuk video yang beisikan penyampaian informasi dakwah kepada pengguna facebook yang bergabung dalam grup tersebut.

b) Twitter

Media sosial ini merupakan layanan social networking yang termasuk pada kategori mikroblogging.Media sosial ini memiliki fitur untuk menerbitkan suatu postingan singkat atau status serupa dengan SMS yang dapat diakses dalam internet.

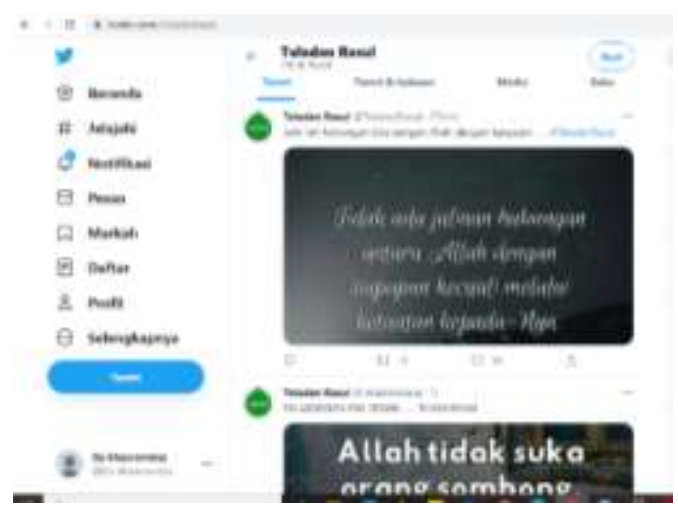

Gambar 2. Contoh media sosial twitter @TeladanRasul sebagai alat dakwah

Penyampaian pesan dakwah menggunakan media sosial twitter pun sama dengan facebook, yaitu dengan media dakwah berbentuk tulisan-tulisan, gambar-gambar komik, foto-foto bahkan kuliah-kuliah dakwah yang berisikan materi dakwah, namun media sosial twitter tidak dapat menyampaikan dakwah dalam berbentuk video dakwah.

c) Youtube
Media sosial ini diluncurkan pada bulan mei 2005. Youtube memudahkan orang untuk menemukan, menonton, dan membagikan beragam video serta memberikan penyediaan forum untuk orang-orang agar dapat saling berhubungan, memberikan informasi, dan menginspirasi orang lain di seluruh dunia.

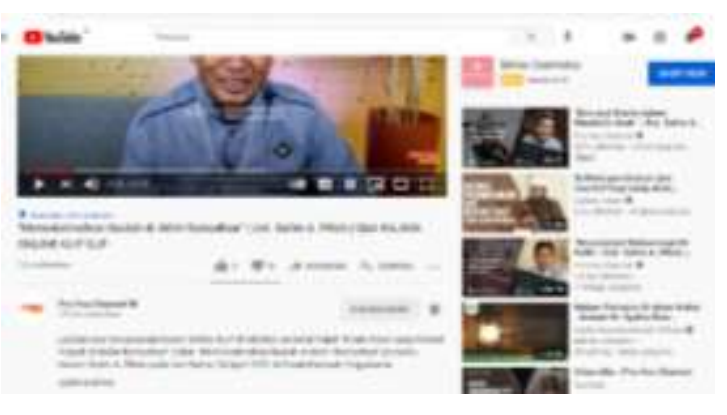

Gambar 3. Contoh media sosial Youtube Pro-You Channel sebagai alat dakwah

Penyampaian dakwah menggunakan media sosial youtube berbeda dengan media sosial twitter, media sosial youtube menyampaikan dakwah dalam bentuk video maka bentuk penyampaiannya adalah dengan metode ceramah (satu arah). Namun media sosial youtube juga memiliki forum komentar yang dapat diisi oleh pengguna youtube lainnya untuk memberikan feedback atau ulasan dari isi dakwah yang disampaikan oleh da'i.

d) Instagram

Media sosial instagram merupakan aplikasi yang memberikan layanan berbagi foto yang memungkinkan penggunanya untuk berfoto dan memfilter lalu menyebarluaskannya di media sosial seperti media sosial facebook, twitter dan media sosial lainnya. 


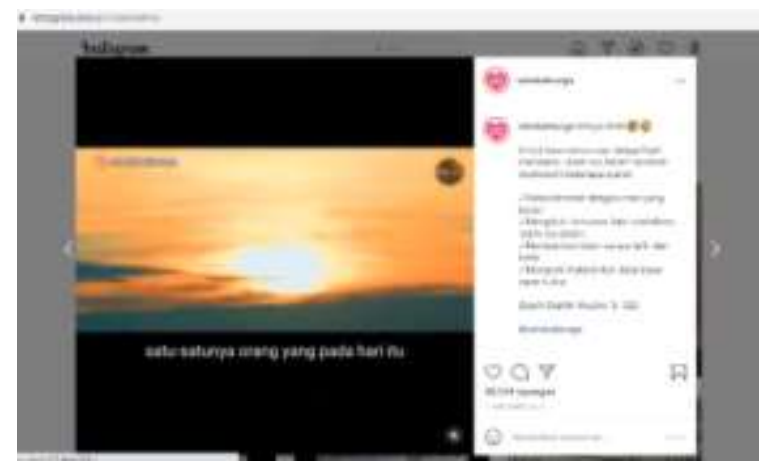

Gambar 4. Contoh media sosial Instagram sahabatsurga sebagai alat dakwah

Media sosial instagram dapat menyampaikan dakwah dengan metode al-hikmah dan metode dakwah Al-Mau'idzat al-Hasanah.media dakwah yang dapat digunakan pada media sosial instagram yaitu dengan gambar-gambar komik atau foto-foto berisikan dakwah disertai dengan tulisan-tulisan atau kuliah-kuliah dakwah, bahkan dapat mengirimkan video dakwah seperti pada gambar.3 di atas menggambarkan sebuah video yang disertai dengan tulisan-tulisan dakwah yang mejelaskan dari isi video.

e) Whatsapp

Media sosial Whatsapp merupakan media sosial yang dapat mengirim dan menerima berbagai macam media: teks, foto, video, dokumen, lokasi, dan juga panggilan suara, bahkan penggunanya dapat mengirim foto dan video pada fitur status yang dapat dilihat oleh semua kontak yang berada di whatsapp.

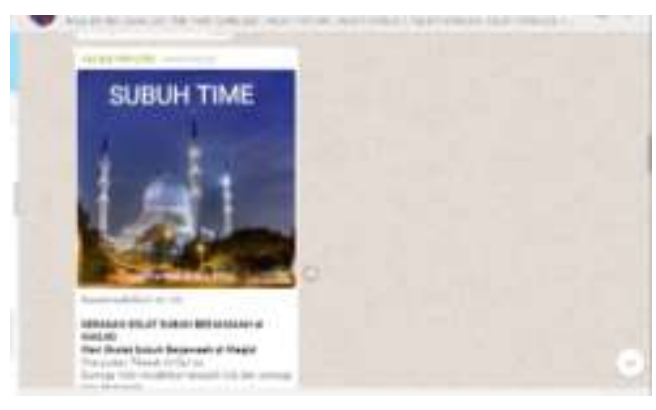

Gambar 5. Contoh media sosial Whatsapp sebagai alat dakwah

Media sosial whatsapp menyebarkan dakwah dengan metode al-mujadalah atau metode diskusi dua arah karena di dalamnya terdapat forum bersama yaitu setiap anggota grup dapat menyampaikan feedback atau komentar dari setiap dakwah yang disampaikan oleh da'i. Namun media sosial dakwah dalam grup whatsapp memiliki pengaturan grup yang dimana admin grup dapat merubah dari komunikasi dua arah menjadi komunikasi satu arah.

Media sosial yang terpopuler pada masa kini yaitu youtube. Media sosial youtube berhasil menjaring 170 juta pengguna atau 93,8\% dari total keseluruhan populasi 181,9 juta pengguna internet berusia 16-64 tahun. Posisi kedua media sosial terpopuler yaitu whatsapp dengan presentase $87,7 \%$ atau 159,5 juta orang. Kemudian dibawah media sosial whatsapp ada instagram dengan jumlah pengguna mencapai $86,6 \%$ atau 157,5 juta orang. Kemudian di belakangnya ada facebook dengan presentase $85,5 \%$ atau 155,5 juta orang. Kemudian posisi kelima media sosial terpopuler yaitu twitter 
dengan meraih pengguna sebanyak $63,6 \%$ atau 115 juta pengguna (Prastya 2021).

Pada masa pandemi virus covid 19, merupakan keadaan yang tidak berada dalam kondisi normal yang dapat memberikan dampak dalam berbagai aspek kehidupan, di mulai dari aspek sosial, aspek pendidikan, aspek ekonomi dan bahkan berdampak pula pada aspek keagamaan yang berkaitan dengan kegiatan keagamaan yaitu kajian-kajian dakwah (Fauzi 2020, 27). Jika pada kondisi normal, pelaksanaan dakwah dilakukan dengan cara interaksi langsung yaitu seperti tabligh, tarbiyah, tausiyah, ta'lim. Dengan begitu pada masa pandemi saat ini tentu sangat sulit untuk dilakukan karena peraturan pemerintah yang mengharuskan masyarakat melakukan social dan physical distancing agar menekan angka penyebaran virus covid 19 ini, sehingga acara pelaksanaan dakwah-dakwah di masjid, majelis ta'li, madrasah dan tempat lainnya yang memungkinkan masyarakat berkumpul tidak dapat dilaksanakan.

Dengan hadirnya media sosial, memudahkan para da'i untuk melakukan dakwah dengan cara memanfaatkan media sosial sebagai alat komunikasi dakwah pada masa pandemi. Para da'i semakin kreatif dalam mengemas materi dakwah untuk dibagikan kepada masyarakat luas dengan membuat tulisan, kuliah-kuliah pamphlet, foto-foto yang mengetuk kalbu, komik-komik berisi dakwah, video ceramah dan lain sebagainya disebarkan menggunakan media sosial seperti grup whatsapp, up date status whatsapp, beranda facebook, youtube, twittwe dan alat media sosial lainnya sehingga dengan menggunakan media sosial dapat memudahkan pesan dakwah islam menyebar luas ke seluruh dunia tanpa adanya rasa khawatir akan penyebaran virus covid 19.

Dengan menyebarkan tayangan video atau tulisan dakwah islam di sosial media seperti facebook, youtube, instagram, twitter, dan media sosial lainnya, pesan dakwah islam dapat dengan mudah tersampaikan kepada objek dakwah terutama pada kalangan umum yang sibuk dengan pekerjaan kantor dan tidak sempat mengikuti kajian-kajian keislaman secara langsung baik dari kalangan anak-anak, remaja dan kalangan orang tua, bahkan dengan dakwah menggunakan media sosial, banyak yang mendapatkan hidayah setelah menonton video tayangan dakwah keislaman dari banyak ustadz di media sosial.

Dengan memanfaatkan media sosial dalam berdakwah dapat meningkatkan jumlah jamaah, pesan dakwah dapat dengan mudah di dengarkan dan dibaca berulang-ulang oleh pendengar atau pembaca, dan tentunya jarak fisik tidak menjadi halangan atau rintangan.

Pada masa pandemi covid-19 tidak menyurutkan semangat para da'i untuk tetap berdakwah, dengan meningkatkan kreatifitas para da'i dapat memanfaatkan media sosial sebagai alat komunikasi dakwah untuk menjangkau mad'u yang lebih luas untuk menyebarkan infomasi dakwah islam sehingga 


\section{Simpulan}

Berdasarkan dari hasil dan pembahasan di atas dapat disimpulkan bahwa fenomena penggunakan media sosial sebagai alat dakwah pada masa pandemi virus covid 19 tentu sangat membantu, dilihat dari masyarakat tidak lagi dapat berinteraksi secara langsung dan pemerintah mengeluarkan peraturan kepada masyarakat untuk melakukan social dan physical distancing dan Work From Home (WFH) agar menekan angka penyebaran virus covid 19 ini, sehingga acara pelaksanaan dakwah-dakwah di masjid, majelis ta'li, madrasah dan tempat lainnya yang memungkinkan masyarakat berkumpul tidak dapat dilaksanakan.

Dengan hadirnya media sosial, memudahkan para da'i untuk melakukan dakwah dengan cara memanfaatkan media sosial sebagai alat komunikasi dakwah pada masa pandemi. Dengan membuat tulisan, kuliahkuliah pamphlet, foto-foto yang mengetuk kalbu, komik-komik berisi dakwah, video ceramah dan lain sebagainya disebarkan menggunakan media sosial facebook, twitter, instagram, youtube dan whatsapp sesuai dengan sarana yang tersedia pada media sosial tersebut.

Pesan dakwah islam dapat dengan mudah tersampaikan kepada objek dakwah terutama pada kalangan umum baik dari kalangan anak-anak, remaja dan kalangan orang tua, dengan bergabung dengan grup atau mengikuti siaran dakwah pengguna dapat mengakses media sosial untuk mendapatkan infomasi dakwah dengan materi seputar akidah, syari'ah, muamalah dan akidah sesuai dengan kebutuhan dakwah bagi pengguna.

\section{Daftar Pustaka}

An-Nabiry, Fathul Bahri. 2008. Meniti Jalan Dakwah Bekal Perjuangan Para Da’i. Jakarta: Amzah.

Fauzi, Ahmad. 2020. "Problematika Dakwah Di Tengah Pandemi Covid 19 Mewabah." Jurnal Al-Hikmah 18 (1): 27-36. https://doi.org/10.35719/alhikmah.v18i1.22

Helmy, Masdar. 1976. Dakwah Dan Pembangunan. Jakarta: Wijaya.

Hidayatun, Umi. 2015. "PENGARUH INTENSITAS PENGGUNAAN MEDIA SOSIAL DAN DUKUNGAN TEMAN SEBAYA TERHADAP PERILAKU KONSUMTIF PADA SISWA KELAS XI SMA MUHAMMADIYAH 3 YOGYAKARTA TAHUN PELAJARAN 2014/2015." Jurnal Riset Mahasiswa Bimbingan Dan Konseling.

Lexy J Moleong. 2009. Metodologi Penelitian Kualitatif. Edisi Revisi. Bandung: Remaja Rosdakarya.

Nasrullah, Rulli. 2015. Media Sosial: Perspektif Komunikasi, Budaya, Dan Sosioteknologi. Bandung: Simbiosa Rekatama Media.

Ngalimun. 2017. Ilmu Komunikasi Sebuah Pengantar Praktis. Yogyakarta: Pustaka Baru Press.

Prastya, Dythia Novianty \& Dicky. 2021. "YouTube Rajai Media Sosial Di Indonesia." $\quad$ Suara.Com. 2021. https://www.suara.com/tekno/2021/02/15/1 53000/youtube-rajai-media-sosial-diindonesia.

Rahma, Farida Nur, and Mada Wijaya Kusumah. 2020. "YOUTUBE SEBAGAI MEDIA DAKWAH MASA PANDEMI COVID 19 (Studi Analisis Konten Dakwah Channel Muslimah Media Center 15-30 Juni 2020)." Dakwah Di Masa Pandemi Covid- 
19 19: 41-54.

Renel, Baiti. 2012. "Materi Dakwah Dan Kebutuhan Mad'u." UIN Alauddin.

Rustandi, Ridwan. 2019. "Cyberdakwah: Internet Sebagai Media Baru Dalam Sistem Komunikasi Dakwah Islam." NALAR: Jurnal Peradaban Dan Pemikiran Islam 3(2): 95.

Saputra, Wahidin. 2011. Pengantar Ilmu Dakwah. Jakarta: Raja Grafindo.

Soyomukti, Nurani. 2012. Pengantar Ilmu Komunikasi. Yogyakarta: Ar-Ruzz Media. 